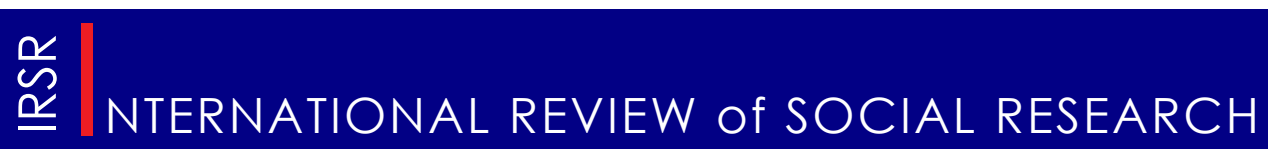

\title{
Social Cooperatives in Greece. Introducing New Forms of Social Economy and Entrepreneurship
}

\author{
Ioannis NASIOULAS* \\ Social and Political Institutions Academic Laboratory \\ Sociology Department, University of the Aegean
}

\begin{abstract}
In this article, we investigate on the historical and civic foundations, along with emerging potentials of social cooperatives in Greece. Constituting the most innovative actor of social economy in the country, currently introduced institutional forms of social cooperatives enhance an already plural and vibrant field of not-for-profit activity, which was regrettably left to stagnate under political patronage and structural deficiencies. The introduction of Social Entrepreneurial Cooperatives by Law 4019/2011 and the explicit recognition of social economy for the first time, provide for a decisive jumpstart toward a viable structuration of the field. Along with a concise theorization on the concepts of social economy and social enterprise, a (highly practical for non-Greek speaking readers) integrated register of cooperative entities, cooperative legislation and auditing authorities in Greece is annexed.
\end{abstract}

Keywords: Social, economy, enterprises, cooperatives, Greece.

\section{Introduction}

We will begin our discussion by conceptualizing on the social economy and social enterprises as theoretical constructions of the European tradition and as fields of practices invaluable to social cohesion, civic self-organization and viable economic development. We shall have the chance to discuss the rich past and the inner dynamics of the cooperative field and comment on currently introduced legislative initiatives on social cooperatives that enhance operational capacity and institutional visibility of the social economy in Greece.

The concept of social economy is inherently intriguing, since it has managed to incorporate not only traditional visions for a more humane and ethical reorientation of economic activity, but also due to its recent promising success, especially in

e-mail: ioannisnasioulas@gmail.com 
continental Europe and Canada. The overall vision that a not-for profit market activity would be viable, effective and widely acknowledged in the public sphere has for at least two decades materialized in ways promising for its future development. The practice and institutional conception of social enterprises, in their plural organizational forms, has provided with one more solid means in achieving socially oriented goals, providing products and services in the market. Associations, foundations, mutual funds and conventional cooperatives are now backed by social cooperatives of many kinds and this is by far the most rewording example of how dominant economistic biases were far from being accurate and rightful, concerning the viability and effectiveness of social economy.
Greece presents a rich and deep social economy past, with most of the conventional social economy organizations being prominently active into the nation-building processes of the $19^{\text {th }}$ and the social development visions of the $20^{\text {th }}$ century. Nevertheless, social economy has only recently (2011) been institutionally recognized and this in an extremely inadequate and vague manner, inconsistent with the European conceptual tradition. Notwithstanding many administrative and legal deficiencies, social economy in Greece today at least possesses firm ground to surpass long standing underdevelopment and proceed to meet future challenges, now heavily burdened by the dramatic fiscal crisis erupted in 2010. The introduction of innovative forms of social cooperatives is thus to be investigated not only

Table 1: The Social Economy in Greece

\begin{tabular}{|c|c|c|c|}
\hline The Social Economy in GREECE 2012 (1) & $\begin{array}{c}\mathrm{N}^{\mathrm{o}} \\
\text { enterprises }\end{array}$ & $\mathrm{N}^{\circ}$ Jobs & Members \\
\hline $\begin{array}{l}\text { Cooperatives and other similar firms. } \\
\text { TOTAL }\end{array}$ & 7.197 & 14.983 & 1.052 .785 \\
\hline - Cooperative banks & 25 & 1.238 & 196.179 \\
\hline - Agricultural Cooperatives & 6.376 & 11.300 & 713.714 \\
\hline - Housing Cooperatives & 545 & $\mathrm{n} / \mathrm{a}$ & 120.242 \\
\hline - $\quad$ Electricians' Cooperatives & 23 & 200 & 600 \\
\hline - $\quad$ Plumbers' Cooperatives & 33 & 200 & 2.500 \\
\hline - Women's agro-tourist cooperatives & 130 & 100 & 2.000 \\
\hline - $\quad$ Pharmacists' cooperatives & 41 & 1500 & 5.500 \\
\hline - $\quad$ Limited Liability Social Cooperatives & 16 & 400 & 2.000 \\
\hline - $\quad$ Mutual Insurance Cooperatives & 7 & 40 & 10.000 \\
\hline - Sea Mutual Insurance Cooperative & 1 & 5 & 50 \\
\hline $\begin{array}{l}\text { Mutual Societies and other similar forms. } \\
\text { TOTAL }\end{array}$ & 11 & 1.140 & 180.000 \\
\hline - Mutual Help Funds & 4 & 1.100 & 150.000 \\
\hline -Occupational Insurance Funds & 7 & 40 & 30.000 \\
\hline $\begin{array}{l}\text { Associations, foundations and other } \\
\text { nonprofit and voluntary organisations. } \\
\text { TOTAL }\end{array}$ & 50.600 & 101.000 & 1.500 .000 \\
\hline - Associations in general & 50.000 & 100.000 & 1.500 .000 \\
\hline - Foundations & 600 & 1.000 & - \\
\hline - Civil non-profit companies & $\mathrm{n} / \mathrm{a}$ & $\mathrm{n} / \mathrm{a}$ & $\mathrm{n} / \mathrm{a}$ \\
\hline SOCIALECONOMY & & & \\
\hline
\end{tabular}

Source: Nasioulas, 2012. 
as an operational contribution to the structuration of social economy in Greece, but also as a direct enhancement of self-organization capacity in the public sphere.

\section{Social economy and the social enterprises}

The concept of social economy is a genuine product of the European socio-economic context. To the $19^{\text {th }}$ century, application of the term 'Social economy' was utilized as a means of revisiting market values and dominant narratives of political economy, where economic rules appeared inconsistent to ethical considerations. There emerged an emphatic debate over the reconciliation of market economy and human society. Some of its implicit roots were the religious conceptualization of man against wealth, a need for moral economic practices, socialist points of political view aiming at the emancipation of labor away from market oppression, alongside with a liberal economic logic focusing on surmounting market failures. With Charles Gide in the turning of the $19^{\text {th }}$ century and his work L'économie sociale, Social economy ceases to describe a vision of a more humane and moral economic order or a critical version of traditional political economy. From now on, Social economy will adhere to its modern conceptualization as a field of the public sphere or as a branch of economic activity located between the public and the private.

The term dynamically reappears with its modern connotations in the 1970s. In 1977, sociologist Henri
Desroche introduces the term 'social economy enterprises' and the same year, the European Economic and Social Committee (EESC) organizes a conference where cooperatives, mutual aid funds and associations are categorized under a common field. Some years later, in 1980, the Chart of social economy is published. Here, social economy is defined as the sum of organizations which are not public, operate in a democratic manner, and provide for member equality, solidarity and the same ownership status for all participants. A special status for distribution of profit is provided, where any surplus is not allowed to be used in any other way than of serving members' needs. Control is granted only to members (Archambault, 1997, Defourny \& Develtere, 1999, Demoustier \& Rousellier, 2005, Laville, Levesque \& Mendell, 2006, CIRIEC, 2007, Vienney, 2008).

In 1994, Claude Vienney publishes his seminal work $L$ 'économie sociale. Vienney's work is of multifaceted conceptual and practical value, as a snapshot of French social economy, exactly at the time when consistent efforts were put to establish it as an autonomous field of the public sphere. He explained the emergence of Social economy as a direct defense reaction of cooperatives, mutuals, associations and foundations to the transformation of economy; expansion of commercial production and the disengagement of the state out of their funding created the need for compromise between commercial exchange and public commitment, economic effectiveness and social utility. Along, he foresaw the constant rejuvenation of the Social economy field, with some 
of its organizations discarding their characteristics and others evolve in form and practices. Dominant political economy paradigm -'economy of the economists' - is not in position to recognize such peculiarities; it restrictively approaches products as commodities, capital efficiency is measured according to profits and only activities with the maximum of productive capacity are considered most efficient. The foundation of reciprocity is not recognized (Vienney, 2008).

Settling the ground for future elaboration and detailed recognition (CIRIEC, 2000, 2007), a collateral European Union level initiative published the Chart of the Social economy Values, featuring the following basic principles:

- The primary importance of people and society over capital

- Voluntary and equal participation

- Democratic control by members

- The combinations of individual and general interest

- Solidarity and responsibility

- Autonomous operation and independence from the state

- Commitment that the majority of surpluses will be invested in viable development and services towards members and the society (CEP-CMAF, 2002, 2).

Social enterprises are organizations of the social economy, which serve, produce and offer services and goods in the market. As a concept, social enterprise emerges in the literature in the early 1990's. In the United States and Britain, however, the approach is different from that found in continental Europe and Canada. In the Englishspeaking world, there is the narrative of non-profit, voluntary and community sector. In continental Europe, the main approach is expressed through the third system and social economy.

In Britain and the United States, social enterprises are acknowledged more as business ventures with social purposes. Emphasis is given to profitmaking for charitable purposes, in the self-finance of non-profit organizations, into their attribute as 'venture', 'project', and their primary character as 'business': 'Social enterprise is a business with primarily social objectives whose profits are reinvested for related purposes, inside the business or into the community rather than treated to maximize profits for their shareholders or owners' (Campbell, 2006: 19).

In continental Europe, the debate about social enterprises was triggered when Italy introduced its 1991 Law on Social Cooperatives. A typical European definition would refer to social enterprises as 'organizations with a clear objective towards the benefit of the community, created by a group of citizens to whom the material interest of capital investment is subject to restrictions' (EMES, 2006, 5).

According to Defourny and Nyssens the following corporate and social criteria distinguish a social enterprise: (a) it is an entity with stable activity related to production and distribution of goods, (b) it enjoys a high degree of autonomy, (c) it undertakes substantial financial risk, and (d) involves a minimum amount of 
paid work. From a social perspective, social enterprises (e) are formed with a clear view to benefit the community, (f) they constitute an initiative of a group of citizens, ( $g$ ) participation in the decisions is not based on ownership of capital (h) producers and recipients are represented (i) distribution of profits and surpluses is limited (Defourny \& Nyssens, 2006: 5-6).

Policy Research Initiative in Canada (PRI Project) refers to social enterprises as follows: "The social economy enterprises are organizations democratically controlled by their members or shareholders, using a combination of market (revenue from sales and paid work) and non-market resources (government grants, private philanthropy and voluntary work) to produce and distribute goods and services in the market, based on a combination of the common interests of members and their concern for the welfare of others. They are led by citizens as community-based organizations that provide goods and services locally, sometimes as part of a network of similar organizations, sometimes with the help of other organizations that provide financial, strategic and technical support' (PRI, 2006: 2).

Promising are Work Integration Social Enterprises. 'Work Integration Social Enterprises are autonomous entities, whose main goal is the professional integration - within the company or other - of people who face serious difficulties in the labor market. Integration is achieved through productive activity and specialized monitoring, or through training of workers. Work Integration Social Enterprises are active in several areas, but most common in Europe are: builders, carpenters, etc., collection and recycling services, green packaging products' (Davister, Defourny \& Olivier, 2004: 3). Four main methods of integration were recorded: providing work experience, creating permanent self-financed jobs (using loans for start off), providing permanent subsidies (e.g. for people with severe disabilities), enhancing socialization through productive activities (informal employment for the social reintegration of disadvantaged or marginalized people) (Davister, Defourny \& Olivier, 2004: 4-5).

\section{Cooperative activities, Greek community system and the social capital stock}

Cooperative activities in the Greek domesticity, through the age-old community system, reproduced a decisive stock of social capital. This body of meaningful ties was deployed in favor of social cohesion during the Ottoman rule (14531821); the ethnic group of 'Romioi' (civilians of Byzantine Empire, of Greek descent, culture and Christian Orthodox religious faith) selforganized in autonomous ways, excelled in conserving, expanding and revitalizing international commercial networks, both for subsistence and market economy, throughout the Balkans, central Europe and the eastern Mediterranean. Communitybased productive clans were decisively active in the national liberation wartime activities of 1821. Following the national liberation, they kept pushing towards democratic governance of the 
rural social reproduction in parallel with national integration during the $19^{\text {th }}$ and $20^{\text {th }}$ century (Nasioulas, 2010: 111-162, 239-298).

Subsistence, productive and civic, self-organization was highly developed in the Greek cultural space already since the classical times and, in a more modern form, since the Byzantine era. Greek cooperative traditions are maybe the oldest in Europe. Institutionalized livestock cooperatives have been widespread throughout the last centuries in many areas of Greece, under the Greek appellations 'syntehnies', 'synafia', 'tseligata', 'mitata', 'sempries', 'paradiarika', 'konakia' and 'koinata'. As these appellations linguistically show, a solid connotation to the ancient term 'koinon' is being made - 'koinon' meaning common, joint, reciprocal or political. These primal cooperative forms facilitated the union of individual owners into a common productive basis and management of the livestock. Stockbreeding clans were divided hierarchically in different roles: at the top was a leader-shepherd responsible for all activities. He represented the clan in all agreements with third parties, such as fixing rents and selling milk products. In the middle, there were the heads of families in charge of the transactions. At the productive and lower group, there were the shepherds providing their labor under salary. It is evident that such kind of extended productive and subsistence activities involved equally important social and ethical ties in clan and reciprocal local context. Above all, such cooperative schemes were closely tied to a nomad way of life peculiar to the Greek tribes of Sarakatsanoi and Vlachoi. Their cyclical and repetitive relocation in various regions followed the seasonal changes. With the onslaught of the refugee masses, following the 1922 Asia Minor demise, this way of life began to fade, since a stable family and productive locale became indispensable. Also, after 1938, all nomads were obliged to conscript to the national armed forces and of course subscribe to official birth registrars (Nasioulas, 2010, 2011).

Around the $18^{\text {th }}$ century, sectoral cooperatives in land mining appear in Chalkidiki, Northern Greece, at the Mantemohoria villages. The Mantemohoria cooperatives schemes were exclusively involved in mining, bearing special privileges granted from the Ottoman Sultan's occupying authority located at the city of Stageira, birthplace of the Greek philosopher Aristotle, in Chalkidiki.

Already since 1770 and around 1750-1770, 22 villages in Tempi, Central Greece, formed several smallsized cooperatives which eventually united into a single modern version of cooperative known as the 'Common Company of Ampelakia' in 1772, providing European markets with high quality yarn products. This included a vertical productive process from cultivating cotton, to processing it into yarn, then painting it into a distinctive indigenous red coloring and finally forwarding it into European markets. At first, all small groups of producers in the villages, which were called 'syntrofies' (companies or friendships), decided to cooperate with each other, in order to avoid unnecessary rivalry and competition. The common scheme created included some 6.000 individual members and 24 factories. Amongst 
them there were (a) financiers and land-owners providing for capital and land, (b) technicians providing knowhow and (c) workers providing labor. According to its Statute, the General Assembly was formed by all locals over 21 years of age. The Board of Directors had 11 members. There were 5 Committees over Strategic Planning, Management, Agricultural, Industry and Control. Then on, the Common Company of Ampelakia entered the European market facing international competition from an advantageous position. It came to operate 17 branchstores around Europe amongst which were Amsterdam, Constantinople, Dresden, Hamburg, Leipzig, London, Lyon, Odessa, Smyrni, St. Petersburg, Thessaloniki, and Trieste. The Ampelakia cooperative is considered the first modern cooperative in the world and had come to be one of the major enterprises in Europe, with a cooperative capital of around 20 million piastra. It has created considerable assets for its members (social insurance, health facilities, schools and the Free University of Ampelakia, libraries etc) and significant wealth which can be verified by the quality of architecture and infrastructure in the village. The cooperative was dissolved in 1812 under heavy tax pressure from the Ottoman ruler Ali Pasha and concurrent economic and productive developments in the industry of yarn production (Kalitsounakis, 1929: 224231).

From the middle of the $18^{\text {th }}$ century to the national revolution of 1821 against the Ottoman rule, maritime cooperatives flourished in the Greek islands of Ydra, Spetses and Psara. Financiers along with seamen and traders contributed financial capital, expertise and labor into a common property scheme for building ships and conducting commerce throughout the Mediterranean Sea and even farther as far as Latin America. Out of the total, only a small percentage of vessels were private property. With the outburst of the Greek revolution, this Greek cooperative fleet was already sizable with over 160 vessels and was decisively deployed in the wartime operations at the sea. Along, all existing social, subsistence and productive networks throughout the Greek cultural space proved decisively active in maintaining social cohesion and promoting national liberation in those turbulent times (Papageorgiou, 2004).

After 1870, some cooperatives and entrepreneurial associations are established mainly in Athens, paving the way for the major development of the cooperative movement in the beginning of the $20^{\text {th }}$ century in Greece. The first significant effort was the establishment of the 'Participial Agricultural Fund of Mutual Help' in Almyros of Thessaly, modern day Central Greece (1906). Other collectivities followed undertaking the form of enterprise or association, since to 1915 no official institutional provision existed in Greece as far as cooperatives were concerned.

\section{The cooperative field in Greece: 1915-2011}

Law $602 / 1914$ was the first to officially introduce the cooperative concept and entity in Greece. It has been discussed as an attempt to reconcile State control 
over production policy, small land owners' rights and major landholders' vested interests (Lambos, 1999: 129139). Under this Law, it was evitable for the first time for the Greek state to organize the cooperative movement and agricultural policy in general upon a firm basis, notwithstanding the critique that 'the Greek State moved to a tight embracement of the agricultural cooperatives reducing them exclusively to tools of its own agricultural policy' (Patronis, 2001: 3) Many agricultural and financial cooperatives were established, in attempt to getting over with loan sharks, middle-men and the enhancement of creditworthiness.

The cooperative spring of 1914 contributed to the great agricultural reform of 1923-1932, the years after the Asia Minor demise. The onslaught of about 1.500.000 refugees from Asia Minor after the demise of 1922 created an internal social and economic crisis and this momentum pressed forward the cooperative activity. It produced immense pressure through the relocation of thousands of agricultural refugee families, overthrew previous socio-economic procedures relating to the interests of old warrior families of the 1821 Independence Revolution, internal asphyxia in the market, urgent need for increase in agricultural production to feed the refugee masses along with demographic and ethnological issues in the province of Macedonia, Northern Greece. All in all, the concurrent great reform of the agricultural production in Greece was the byproduct of the territorial expansion of the Greek space through the Balkan during the First World War, of the Asia Minor demise and a top-down State implemented policy
(Rigos, 1999: 38-51).

The extremely unbalanced, costineffective and poor development of the Greek agricultural activity pushed the way through to the establishment of the Agricultural Bank of Greece, taking over from the National Bank of Greece, with a major role in supporting a viable agricultural reproduction for the masses in 1929. In the interwar period, state intervention of the cooperative movement institutionalized further, in fact abolishing joint liability of cooperative partners and safeguarding the banking system's interests through funding conditionalities. Nevertheless the presence and activity of the Agricultural Bank has been invaluable at times of intense agricultural crises, involving the international market demise of grapes and tobacco monocultures through the 1930's. Additionally, the Greek state proceeded into establishing many compulsory cooperatives for special cases, in order to cope with the problems of agricultural colonization and the restitution of landless cultivators and refugees from Asia Minor. As international market forces kept pressing domestic production, state intervention deepened; extremely centralized state organizations on agricultural production management were established; the role of cooperatives was restrained in marginal and secondary activities, mainly through providing of shortterm loans to farmers; "Although Greek farmers fought over their rights, the benefits they were given were frequently conceived as a gift rather as an earning' (Patronis, 2001: 3).

In 1935, the All-Greek Confederations of Unions of 
Agricultural Cooperatives 'PASEGES' was established. After the imposition of the Ioannis Metaxas dictatorship regime in 1936, there has been intense interference into the cooperative movement and activities with the aim of ensuring the political stability of the regime. Nevertheless, the Metaxas regime favored agricultural development through a policy of massive lending towards individual land owners and cooperatives, and through a central foreign exchanges policy with Germany and the United Kingdom (Papagarifallou, 1973, Rigos, 1999)

The Second World War and the concurrent Greek Civil War destroyed national agricultural activity, which gradually recovered the following decades. After the end of the GermanItalian-Bulgarian occupation of Greece and until the establishment of the 1967-1974 military dictatorship, agricultural production and cooperative development gradually recovered but the overall state patronage was not altered significantly. Nevertheless, cooperatives turned to a new innovative idea, that of establishing cooperative enterprises in many fields of production, processing and marketing. Agricultural and economic development continued through the dictatorship period (19671974).

Following the restoration of democracy in Greece (1974) the main effort was to stabilize the social and political environment and to recover from the national disaster of the Turkish invasion in and occupation of Cyprus. Agricultural cooperatives mobilized clientele networking in order to solidify their benefits and maintain favorable price levels. Throughout the
1980 s, along with the populist socialist new government, a major cooperative reform took place in expression of this wider social expectation. Its political narrative referred to the promotion of democratic decision making in cooperatives. Basic provisions of 1983 and 1985 legislative actions could be summed up as follows:

1. Voting through representatives, the majority system, and multiple voting was abolished

2. The 'one-person-one vote' principle was established

3. Politically-driven party lists were introduced

4. Agricultural cooperatives were allocated financial resources and public administration authorities

5. Economic auditing of the Agricultural Bank of Greece was abolished

Such policies applied eventually led to devestating consequences for the cooperative movement and agricultural production: cooperatives began to be extremely politicized, through the expansion of the patronage and clientele system into their operations, many non-viable investments were made, a negative interlink of the State into cooperative issues was imposed and the total overdue dept of cooperatives towards the Agricultural Bank led to the eventual demise of the agricultural cooperative system in Greece. Along with political patronage, the most negative of all the related developments was the inexcusable relaxation of the Agricultural Bank supervision over cooperative activities.

Though major efforts were made in the $90 \mathrm{~s}$ to reform and consolidate cooperatives in Greece, to this day, 
no serious overturn of this negative image has been witnessed. It has been argued that the cooperative movement in Greece suffered a temporal disorientation, fragmentation, and has been consistently underactive. The majority of agricultural cooperatives are not involved in productive activities. The overall cooperative body is fragmented, with an inflation of cooperative enterprises and cooperative unions competing in local and peripheral level. The majority is also underactive providing for little employment. This situation is paired with an extensive and eventually toxic political manipulation of the cooperative movement in Greece. Political parties have occupied cooperative activity in order to control and disseminate political power at national, regional, local and sectoral level (Lambos, 1999, 73-74, Patronis, 2001).

There exists 'PASEGES', the AllGreek Confederation of Unions of Agricultural Cooperatives, established in 1935 and providing for the thirddegree representation of agricultural cooperatives at the national level. Its existence, operation, activity and legitimacy was has been gravely undermined by the establishment of two other competing and politicallydriven confederations: 'GESASE' and 'SYDASE'. This fragmented and politically-manipulated organizational structure of the Greek cooperative movement is indicative of the same extent of fragmentation at a practical level. Agricultural land holdings in Greece are severely segmented. There appear to be some estimated 8.000 .000 individual land holdings and about 7.200 cooperatives, 120 Unions and
19 Central Unions (Kazis, 2005: 2). At the same time, only a 27 per cent of the total available land is exploited. Practical causes regarding this cooperative activity underdevelopment are the relative absence of economies of scale, the long-standing insufficient integration of cooperatives in the globalized capitalist production system and inherent deficiencies in planning and management. Historically, cooperative underdevelopment can be attributed to the critical absence of an active and vital bourgeois in Greece, which condemned society into an ever-evolving fragmentation of the agricultural capital amongst small land-owners, as discussed earlier. This operational absence would also not allow the local production system to be integrated to the international markets. The political context of this deficiency can be attributed to the peculiar structure of local agricultural social reproduction, with major agricultural crises and recurrent policies of imports substitution. With the full accession of Greece into the European Community, this structural deficit concluded at a cyclical domestic agricultural crisis that has not yet been addressed willfully and in effect (Pezaros, 2004, Pezaros, 2005, Patronis, 2001). Further structural deficiencies and the persistent non-recognition of the Social economy field left socially oriented economic activities somewhere between atypical and regrettably illegal (black) economy (Nasioulas, 2010).

Civil cooperatives were fortunately less affected by inherent civic, political and economic deficiencies of the Greek specificity. Promising examples show that a latent capacity exists.

Law 602/1914 provided for the 
reinstatement of the 'Lamia Technical Workers Banking Cooperative', established in 1900; with about 12.000 members, today's 'Lamia Cooperative Bank' is the oldest civil cooperative in Greece. Cooperative banks, especially in medium-sized Greek cities, introduced a regional agenda much more sensitive to local specificities and counterbalancing the usually offensive, market expansion of commercial banking. Law 2076/1992 on 'Banking Cooperatives' was the decisive institutional step which provided for a cooperative banking spring in mid-90's, as shown in Table 1, with local Chambers of Commerce playing a leading role. The Union of Greek Cooperative Banks, with an estimated 120.000 clients, has 25 members, of which 16 are Cooperative Banks, 8 Banking Cooperatives and 1 Banking Foundation, the 'Panellinia Bank S.A.'. This private scheme was created by the 15 larger Cooperative Banks and 13 Banking Cooperatives in Greece, the Central Cooperative Bank of Germany DZ Bank AG and Greek 'PASEGES' (www.este.gr).

Civil cooperatives have mainly been established by state employees, especially civil servants and military personnel, as direct sign of their financial stability, enhanced access to information and preferential regulations under clientelistic connections to the political authority. Though, in general, consumer cooperatives have not thrived and today are almost extinct, vocational cooperatives (electricians, plumbers, craftsmen, pharmacists etc) show a promising trajectory to this date.

The Pharmacists' Cooperatives Federation was established in 1998 and now consists of the existing 41 Pharmacists' Cooperatives all over Greece, with 45 distribution establishments, serving 5.500 drug stores, 1500 employees, and a turnover of 2.5 billion euro in 2009 , with a $50 \%$ market share nationally. The Federation has also established 'PANSYFA SA', a non-pharmaceutical products company, and participates in 'SECOF $\mathrm{SA}^{\prime}$ along with Portugal, Spain, France and Turkey. It now operates the innovative on-line logistics system 'Information System of Cooperatives Pharmacists' (www.osfe.gr).

The Electricians' Cooperatives Federation consists of 23 cooperatives, involves 6000 electricians, 50 commercial establishments and a turnover of 12 billion euro (www. posie.gr).

The Plumbers' Cooperatives Federation 'POSEYD' was established in 1980. It now involves 33 cooperatives and 2.500 plumbers and since 2004 it operates 54 commercial establishments under the trademark 'Ydro', with a turnover of 35 million euro in 2010. It is the leading power in retail and wholesale hydraulic apparels commerce in Greece (www.ydroposeyd.gr). 
Table 2. Cooperative Banks (Foundations, Cooperatives, SAs) in Greece

\begin{tabular}{|c|c|c|}
\hline Entity & Founded & Website \\
\hline \multicolumn{3}{|c|}{ Foundations } \\
\hline Cooperative Bank of Thessaly & 1994 & http://www.bankofthessaly.gr/ \\
\hline Cooperative Bank of Chania & 1993 & http://www.chaniabank.gr/ \\
\hline $\begin{array}{l}\text { Cooperative Bank of Lesvos \& } \\
\text { Limnos }\end{array}$ & 1995 & http://www.lesvos-bank.net/ \\
\hline Cooperative Bank of Dodecanese & 1994 & http://www.bankdodecanese.gr/ \\
\hline Achaiki Cooperative Bank & 1993 & http://www.acbank.gr/ \\
\hline Pankritia Cooperative Bank & 1994 & https://e.pancretabank.gr/ \\
\hline Cooperative Bank of Drama & 1994 & http://www.dramabank.gr/ \\
\hline Cooperative Bank of Evros & 1996 & http://www.evrosbank.gr/ \\
\hline Cooperative Bank of Evoia & 1994 & http://www.eviabank.gr/ \\
\hline Cooperative Bank of Epirus & 1978 & http://www.epirusbank.com/site/ \\
\hline Cooperative Bank of Karditsa & 2000 & http://www.bankofkarditsa.gr/ \\
\hline $\begin{array}{l}\text { Cooperative Bank of Western } \\
\text { Macedonia }\end{array}$ & 1994 & http://www.bankofwesternmacedonia.gr/ \\
\hline Cooperative Bank of Peloponnese & 2005 & http://www.korinthiasbank.gr/ \\
\hline Cooperative Bank of Lamia & 1900 & http://www.lamiabank.gr/ \\
\hline Cooperative Bank of Pieria & 1995 & http://www.pieriabank.gr/ \\
\hline Cooperative Bank of Serres & 1995 & http://www.syntraser.gr/ \\
\hline Cooperative Bank of Kozani & 1995 & http://www.kozanibank.gr/ \\
\hline \multicolumn{3}{|c|}{ Cooperatives } \\
\hline $\begin{array}{l}\text { Banking Cooperative of } \\
\text { Aitoloakarnania 'Aitoliki Pisti' }\end{array}$ & 1994 & http://www.aitpisti.gr \\
\hline $\begin{array}{l}\text { Banking Cooperative of Korinthia } \\
\text { 'Ermis' }\end{array}$ & 1983 & http://www.synermis.kor.forthnet.gr \\
\hline $\begin{array}{l}\text { Banking Cooperative of Arkadia } \\
\text { 'Arkadiki Pisti' }\end{array}$ & $\mathrm{N} / \mathrm{A}$ & N/A \\
\hline $\begin{array}{l}\text { Banking Cooperative of Arta 'Artini } \\
\text { Egiisi' }\end{array}$ & $\mathrm{N} / \mathrm{A}$ & N/A \\
\hline Banking Cooperative of Voiotia & $\mathrm{N} / \mathrm{A}$ & N/A \\
\hline $\begin{array}{l}\text { Banking Cooperative of Kerkyra } \\
\text { 'Ioniki Pisti' }\end{array}$ & N/A & N/A \\
\hline Banking Cooperative of Magnisia & $\mathrm{N} / \mathrm{A}$ & $\mathrm{N} / \mathrm{A}$ \\
\hline Banking Cooperative of Megarida & $\mathrm{N} / \mathrm{A}$ & $\mathrm{N} / \mathrm{A}$ \\
\hline \multicolumn{3}{|c|}{$\begin{array}{l}\text { SAs owned by cooperative entities } \\
\end{array}$} \\
\hline Panellinia Trapeza SA & 2001 & http://www.paneliniabank.gr \\
\hline \multicolumn{3}{|c|}{ Unions } \\
\hline Union of Greek Cooperative Banks & 1995 & http://www.este.gr/ \\
\hline
\end{tabular}




\section{Social Cooperatives in Greece}

The institutional foundation for cooperatives is set primarily by Art. $12 \S 4$ of the Greek Constitution: 'Agricultural and civil cooperatives of any kind are self-managed according to the provisions of law and their statute; they are protected and audited by the state, which is obliged to cater for their development'. This clause accords increased typical status for cooperatives, not only as civic forms of self-organization but also as valuable actors for the national economy.

Law 921/1979 on 'Agricultural Cooperatives' replaced Law 602/1915, which did not distinguish between agricultural and civil cooperatives. Along, from then on, it would be the judicial and not the legislative authority that had jurisdiction over cooperatives, a factor that greatly enhanced their autonomy. Law 921/1979 has been the foundation for social enterprises in Greece. Nevertheless, it was shortlived and eventually replaced by Law $1257 / 1982$ and $1541 / 1985$.

Law $1167 / 1986$ on 'Civil Cooperatives' provides for the establishment of social enterprises free to engage in non-agricultural activities, mainly: productive, consumer, logistics, banking, transport, tourist. It has facilitated the establishment of many women's rural, agro-tourist and local traditions' cooperatives in Greece (www.europe-greece.com).

Provided by Law 2716/1999 on 'Limited Liability Social Cooperatives' (LLSC), a first solid form of work integration social enterprises was introduced in Greece. LLSCs aim at social, psychological and work integration of individuals facing serious psychological and social issues, thus contributing to their therapy and economic self-sufficiency. They are legal entities of private law with commercial faculty and are considered as mental health units. Cooperative members bear limited responsibility. They are supervised by the ministry of health. LLSCs can at the same time be productive, consumer, commercial, logistics, tourist, building, credit, development, social, educational and cultural units. They are free to exert any economic activity. They are free to create commercial establishments anywhere and participate into European groupings of economic purpose, joint ventures, limited liability enterprises, SAs, state and municipal enterprises.

Of extreme importance is the fact that members of LLSCs have the right to be individuals over 15 years of age. Ability of legal transaction is not needed, thus providing for the inclusion of individuals deprived of the right to participate in public activities. This is a strong integration factor. Members have the right of compensation for their work, even if they already enjoy other allowances, pensions or benefits. Alongside, they enjoy the privilege of participating in any profit distribution. Related Registers are kept at the ministry of health which has the right to judge upon the purposefulness of such a cooperative's establishment. In case of limited liability agricultural cooperatives, registers are kept as mentioned in the case of agricultural cooperatives.

To 2011, 16 LLSCs are active in Greece. Their estimated employees reach up to 400 . The $2^{\text {nd }}$ grade association of LLSCs was founded in 2011, providing for their collective representation. 
Table 3. Limited Liability Social Cooperatives in Greece

\begin{tabular}{|c|c|c|}
\hline Entity & Activities & Website \\
\hline $\begin{array}{l}\text { Chios LLSC 'Orion' } \\
12 \text { employees, of which } \\
9 \text { in need of support }\end{array}$ & $\begin{array}{l}\text { Hospital apparel cleaning services, } \\
\text { Biological agriculture, Biological } \\
\text { products store, Broduction and } \\
\text { selling of toys, } \\
\text { Greenhouse agricultural } \\
\text { production, Natural Chios mastic } \\
\text { cultivation and collection }\end{array}$ & http://www.kspechios.gr \\
\hline $\begin{array}{l}\text { Athens LLSC 'Eikona' } \\
25 \text { employees }\end{array}$ & $\begin{array}{l}\text { Graphic design, Printing services } \\
\text { Publishing services / Typing }\end{array}$ & http://www.eikonakoispe.gr \\
\hline $\begin{array}{l}\text { Dodekanese LLSC } \\
441 \text { members } \\
44 \text { employees }\end{array}$ & $\begin{array}{l}\text { Agriculture, Pastry making, } \\
\text { Buffet services, Honey production }\end{array}$ & http://www.koispe.gr \\
\hline $\begin{array}{l}\text { Attica LLSC Klimax } \\
\text { Plus' }\end{array}$ & $\begin{array}{l}\text { Art design, Popular/folk art } \\
\text { Furniture maintenance, Catering } \\
\text { Paper recycling, Cleaning services }\end{array}$ & http://www.koispe.org \\
\hline $\begin{array}{l}\text { Kerkyra LLSC 'Neoi } \\
\text { Orizontes' } \\
70 \text { employees, of which } \\
45 \text { in need of support }\end{array}$ & $\begin{array}{l}\text { Cleaning services, Café-Bar } \\
\text { Parking services, Catering } \\
\text { Pastry making }\end{array}$ & http://www.koispekerk.gr \\
\hline Chania LLSC & $\begin{array}{l}\text { Gift manufacture, Car cleaning } \\
\text { services, Art, Café-bar }\end{array}$ & http://www.koispechania.gr \\
\hline $\begin{array}{l}\text { Fokida LLSC ‘Giannis } \\
\text { Volikas' }\end{array}$ & $\begin{array}{l}\text { Biological products store } \\
\text { Agricultural activities }\end{array}$ & http://www.koispefokidas.gr \\
\hline Attica LLSC ‘Ef Zin’ & $\begin{array}{l}\text { Catering, Delivery, Handmade } \\
\text { furniture, Decoration services }\end{array}$ & http://www.koispe-euzin.gr \\
\hline $\begin{array}{l}\text { Thessaloniki LLSC } \\
110 \text { employees }\end{array}$ & $\begin{array}{l}\text { Farming, Catering, Art House } \\
\text { Carpentry, Greenhouse, Cleaning } \\
\text { services }\end{array}$ & http://www.koispe-thess.gr \\
\hline Achaia LLSC 'Faros’ & Hospital cleaning services & http://www.koispeachaias.gr \\
\hline $\begin{array}{l}\text { Athens LLSC } \\
\text { 'Diaplous' }\end{array}$ & $\begin{array}{l}\text { Cleaning services, Agriculture, } \\
\text { Gardening }\end{array}$ & http://www.diaplous.eu \\
\hline $\begin{array}{l}\text { Kefalonia/Zakynthos } \\
\text { LLSC 'Rota' } \\
16 \text { employees }\end{array}$ & $\begin{array}{l}\text { Café-bar, Wine-house, Catering } \\
\text { Farming }\end{array}$ & http://www.rotasocialcoop.gr \\
\hline Kavala LLSC & Currently under establishment & $\begin{array}{c}\text { http://www.kavalahospital.gr/ } \\
\text { Pub/News/koispe.aspx }\end{array}$ \\
\hline $\begin{array}{l}\text { Athens LLSC } \\
\text { 'Iliotropio' }\end{array}$ & Cleaning services & www.koispe-iliotropio.gr \\
\hline $\begin{array}{l}\text { Attica LLSC } \\
\text { 'Diadromes' }\end{array}$ & Commerce, Cleaning services & N/A \\
\hline Arta/Preveza LLSC & $\begin{array}{l}\text { Greenhouse cultivations, Grocery } \\
\text { store, Cleaning services }\end{array}$ & N/A \\
\hline $\begin{array}{l}\text { All-Greek LLSC } \\
\text { FEDERATION }\end{array}$ & $2^{\text {nd }}$ Grade LLSCs Association & http://www.pokoispe.gr \\
\hline
\end{tabular}




\section{Introducing new forms of Social Cooperatives: Law 4019/2011}

Law 4019/2011 on 'Social Economy and Social Entrepreneurship' was set to implementation in 30 September 2011. It is the first legislative action introducing the concept of Social Economy in Greece. The law consists of 20 articles.

Art. $1, \S 1$ identifies Social Economy as 'the sum of economic, entrepreneurial, productive and social activities, undertaken by juridical entities or associations whose statutory goal is the pursue of collective benefit and the service of wider social interests'.

Art. $2 \S 1$ provides for the introduction of a new form of social cooperative, the 'Social Cooperative Enterprise' (SCE): 'The Social Cooperative Enterprise is established as an entity of Social Economy. It is a civil cooperative with a social cause possessing entrepreneurial capacity by law. The Social Cooperative Enterprise members can be either individuals or juridical entities. Its members participate with one vote regardless of the cooperative shares they possess'.

Art.2, § 2 further elaborates on the kinds of SCEs:

a) SCEs of integration, which focus on integration of individuals belonging to volatile population groups into the economic and social life; LLSCs of the Law 2716/1999 are also considered SCEs of integration. In integration SCEs, at least $40 \%$ of the employees belong to volatile population groups, as defined by Law 4019/201, Art.1 $\S 4$, such as the disabled, addicted, HIV-positive, imprisoned/released, juvenile offenders, unemployed young or women, unemployed over 50 years of age, long-term unemployed, singleparents, large-families members, abused women, illiterate, residents of remote regions, immigrants, refugees.

b) SCEs of care, which focus on production and provision of goods and services of social-care character, towards certain population groups such as the elderly, infants, children, disabled and chronically ill

c) SCEs of collective and productive purpose, which focus on the production of products and the provision of services to meet the needs of collectivity (culture, environment, ecology, education, social benefit services, promoting local products, reserving traditional activities and crafts etc) which also promote local and collective interest, the development of employment, the enhancement of social cohesion and the strengthening of local or regional development.

Art. 14 identifies the entities to enjoy special benefits set by this Law. Along currently introduced SCEs, and LLSCs of Law 2716/1999, the state also recognizes existing juridical entities, which cumulatively abide by the following criteria:

- they have a statutory purpose of social benefit, through the production of goods or the provision of services of collective and social character,

- they present priority of individuals and labor over capital,

- they employ a democratic system of decision-making,

- they enjoy autonomy in management of their activities,

- their profits are utilized primarily on the service of their statutory goals and secondarily 
for any eventual restricted profit distribution,

- they operate on the principle of sustainable development,

- they exclusively belong to one of the three categories described in Art.2, § 2.

This means that women's agricultural cooperatives of Law 1541/1985 and civil cooperatives of Law $1167 / 1986$ could also be considered as beneficiaries of Law 4019/2011, as long as the above criteria are met.

Establishment and operation of SCEs of Law 4019/2011 is provided by Law 1667/1986. A minimum of five members is required. Juridical entities should not be represented with a ratio over $1 / 3$ of the shareholders. Participation of Local Administration Organizations and Public Law Juridical Entities is not allowed, except in the case of SCEs of integration; same applies to already existing LLSCs of Law 2716/1999.

Of specific significance is Art. 7 which states that profits are not to be distributed to members, except in case such members are also employees. In that case, $35 \%$ of the profits may be distributed to them, a 5\% should be reserved and the rest $60 \%$ should be invested in new jobs creation.

SCEs and LLSCs have access to funding by the newly instated 'Social Economy Fund' and the 'National Fund of Entrepreneurship and Development'. Nevertheless, it is not clear yet if all existing cooperative entities are beneficiaries of these funding opportunities. As with LLSCs, members of SCEs have the right of compensation for their work, even if they already enjoy other allowances, pensions or benefits. Remuneration is not conventionally taxed but only under the first tax level, with no other tax charge. One more favorable provision is set by Art. 16, introducing the concept of 'Social Orientation Public Contracts'; all enterprises under Law 4019/2011 could be eligible as outsourcing contractors under special favorable status.

Greece now possesses an integrated range of cooperatives potentially capable of materializing not only conventional but Social Economy visions along (Table 3 ). Nevertheless Law 4019 does not elaborate on the concept of Social Economy. In fact Greece does not have a law on Social Economy yet. The utilization of the term is proved to be superfluous and eventually misleading, since the basic subject of this legislative action is to introduce the SCEs. Second major deficiency of the Law is that it provides for the establishment of a General Social Economy Register which is eventually found not to include any other of the widely accepted (Nasioulas, 2010, 2011a,b, 2012) institutional forms of Social Economy organizations. 
Table 4. Register of cooperative entities provided by Greek Law

\begin{tabular}{|c|c|c|}
\hline \multicolumn{3}{|c|}{ A. Cooperative entities of the Social Economy in Greece } \\
\hline Entity & Legislation & Auditing \\
\hline $\begin{array}{l}\text { Civil Cooperatives } \\
\text { Civil Cooperatives are governed by Law 1667/1986 } \\
\text { and its amendments: Law 2076/1992, 2166/1993 } \\
\text { and 2515/1997. Individuals and organizations may } \\
\text { constitute Civil Cooperatives in the first degree. Such } \\
\text { cooperatives may have a vast array of primary purposes: } \\
\text { consumption, credit, transport, tourism, assurance, } \\
\text { druggist, supplying and market, production, sale. At } \\
\text { least five Civil Cooperatives in the same prefecture may } \\
\text { constitute a Union of Cooperatives. This is the second } \\
\text { degree of representation. Third-degree associations } \\
\text { include sectoral federations of Civil Cooperatives and } \\
\text { the supreme form of representation is the Confederation } \\
\text { of Greek Cooperatives. Civil Cooperatives are } \\
\text { supervised by the Ministry of Economy, Cooperatives } \\
\text { Department. There also exists a Cooperatives Council in } \\
\text { which six of its members come from Cooperatives. Civil } \\
\text { Cooperatives are registered in the General Commercial } \\
\text { Register, kept by Central Department of General } \\
\text { Commercial Register at the Chambers Union according } \\
\text { to Law 3419/2005. }\end{array}$ & $\begin{array}{l}\text { Law 921/1979 } \\
\text { Law 1667/1986 } \\
\text { Law 2076/1992 } \\
\text { Law 2166/1993 } \\
\text { Law 2515/1997 }\end{array}$ & $\begin{array}{l}\text { Central } \\
\text { Administration of } \\
\text { General Commercial } \\
\text { Register at Central } \\
\text { Chambers Union }\end{array}$ \\
\hline $\begin{array}{l}\text { Agricultural Cooperatives - Agricultural } \\
\text { Cooperative Unions } \\
\text { Since the introduction of the inaugurate Law on } \\
\text { cooperatives in 1915, Law } 921 / 1979 \text { was the first to } \\
\text { distinguish between cooperative types, i.e. agricultural, } \\
\text { consumer etc. } \\
\text { Agricultural Cooperatives are governed by Law } \\
2169 / 1993 \text { and its amendments: Law } 2184 / 1994 \text {, Law } \\
2538 / 1997 \text { and Law } 2810 / 2000 \text {. Primary purpose of } \\
\text { Agricultural Cooperatives is the support of agricultural } \\
\text { income, development of agricultural production and } \\
\text { support of the life in the countryside. According to } \\
\text { Presidential Decree PD 590/1985, an Agricultural } \\
\text { Cooperatives Register is kept in local Country Courts. } \\
\text { Specifically for Agricultural Cooperatives Unions, } \\
\text { Cooperative Organizations and "PASEGES" a register is } \\
\text { kept in local District Courts. }\end{array}$ & $\begin{array}{l}\text { Law } 921 / 1979 \\
\text { Law 2169/1993 } \\
\text { Law 2181/1994 } \\
\text { Law 2538/1997 } \\
\text { Law 2810/2000 }\end{array}$ & $\begin{array}{l}\text { Agricultural } \\
\text { Cooperatives Register } \\
\text { at Country Courts } \\
\text { Agricultural } \\
\text { Cooperatives Unions } \\
\text { Register at City } \\
\text { Courts } \\
\text { "PASEGES" }\end{array}$ \\
\hline $\begin{array}{l}\text { Housing Cooperatives } \\
\text { Housing Cooperatives are a form of Civil Cooperative. } \\
\text { Their primary goal is of serving housing needs of the } \\
\text { people. Such institutions are governed by PD } 17 / 1984 \text {, } \\
93 / 1987,2 / 1988,23 / 1990 \text { and } 448 / 1991 \text {. According to } \\
\text { PD 93/1987, Article } 4 \text {, initiative on creating a Housing } \\
\text { Cooperative may be undertaken by a Municipality or } \\
\text { Community, by an appeal of at least } 25 \text { citizens or by } \\
\text { Ministry of Public Works decision. A purposefulness } \\
\text { advisement and related building approvals are also } \\
\text { needed. Housing Cooperatives are excluded by the } \\
\text { obligation to register at the General Commercial Register } \\
\text { under Law } 3419 / 2005 \text {. Registers are kept at the Ministry } \\
\text { of Public Works, Local Government Organizations and } \\
\text { local Country Courts. }\end{array}$ & $\begin{array}{l}\text { PD } 17 / 1984 \\
\text { PD } 93 / 1987 \\
\text { PD } 2 / 1988 \\
\text { PD } 23 / 1990 \\
\text { PD } 448 / 1991\end{array}$ & $\begin{array}{l}\text { Ministry of } \\
\text { Infrastructures } \\
\text { Local Administration } \\
\text { Organizations } \\
\text { Country Courts }\end{array}$ \\
\hline
\end{tabular}




\begin{tabular}{|c|c|c|}
\hline $\begin{array}{l}\text { European Cooperatives - European Cooperative } \\
\text { Companies } \\
\text { In Nice European Summit, European Community } \\
\text { Regulation } 1435 / 2003 \text { was adopted concerning } \\
\text { European Cooperatives or European Cooperative } \\
\text { Enterprises. Mainconcern has beentolift bureaucratic } \\
\text { hindrances in cooperative activities at the European } \\
\text { level. European Cooperative Enterprises are legal } \\
\text { entities of European Community law. They are } \\
\text { companies bearing legal entity, constituted by } \\
\text { individuals or legal entities of public or private } \\
\text { law, residing in at least two European Community } \\
\text { member states and fall under local state law. Each of } \\
\text { these members has one vote. European Cooperatives } \\
\text { in Greece are registered at the General Commercial } \\
\text { Register under Law } 3419 / 2005 \text {. }\end{array}$ & ER $1435 / 2003$ & $\begin{array}{l}\text { Central } \\
\text { Administration of } \\
\text { General Commercial } \\
\text { Register at Central } \\
\text { Chambers Union }\end{array}$ \\
\hline Women's Agricultural Cooperatives & Law $1541 / 1985$ & $\begin{array}{l}\text { Agricultural } \\
\text { Cooperatives Register } \\
\text { at Country Courts } \\
\text { Agricultural } \\
\text { Cooperatives Unions } \\
\text { Register at City } \\
\text { Courts } \\
\text { 'PASEGES' }\end{array}$ \\
\hline Limited Liability Cooperatives & Law $1667 / 1986$ & $\begin{array}{l}\text { Agricultural } \\
\text { Cooperatives Register } \\
\text { at Country Courts } \\
\text { Agricultural } \\
\text { Cooperatives Unions } \\
\text { Register at City } \\
\text { Courts } \\
\text { 'PASSEGES' }\end{array}$ \\
\hline Limited Liability Social Cooperatives & Law 1716/1999 & $\begin{array}{l}\text { Limited Liability } \\
\text { Social Cooperatives } \\
\text { Register at Ministry of } \\
\text { Health }\end{array}$ \\
\hline Cooperative Banks - Credit Cooperatives & $\begin{array}{l}\text { Law } 1667 / 1986 \\
\text { Law 2076/1992 }\end{array}$ & $\begin{array}{l}\text { Central } \\
\text { Administration of } \\
\text { General Commercial } \\
\text { Register at Central } \\
\text { Chambers Union } \\
\text { Central Bank of } \\
\text { Greece }\end{array}$ \\
\hline $\begin{array}{l}\text { Insurance Companies - Mutual Insurance } \\
\text { Cooperatives }\end{array}$ & $\begin{array}{l}\text { Law } 3557 / 2007 \\
\text { Law } 3455 / 2006 \\
\text { Law } 3487 / 2006 \\
\text { Law } 2496 / 1997 \\
\text { Law } 1569 / 1985 \\
\text { Law 400/1970 } \\
\text { Law 2190/1920 }\end{array}$ & $\begin{array}{l}\text { Insurance Companies } \\
\text { Register at Ministry of } \\
\text { Development }\end{array}$ \\
\hline Social Cooperative Enterprises & Law 4019/2011 & $\begin{array}{l}\text { Ministry of Insurance } \\
\text { and Social Solidarity }\end{array}$ \\
\hline \multicolumn{3}{|c|}{ B. Cooperative entities incompatible with the Social Economy in Greece } \\
\hline \multicolumn{3}{|c|}{$\begin{array}{l}\text { Compulsory Cooperatives under Constitution Article 12, Paragraph } 5 \text { are not included in the Greek } \\
\text { Social Economy. Also not included are Private Banks Credit Cooperatives under PD 329/2000 due } \\
\text { to their compulsory nature. }\end{array}$} \\
\hline
\end{tabular}

Source: Nasioulas, 2010, 2011 a\& b, 2012. 


\section{Conclusions}

The concept of social economy emerged as a genuine product of European civic theorization and practice and evolved into the critical mass of a third system between the state notfor profit and private entrepreneurial economy. Social enterprises mirror this structuration process of the notfor profit economy by providing the organizational means of expressing civic and socially oriented economic activities.

In Greece, the practices of social economy along with the cooperative vision have a rich past and a far-reaching value for the modern social formation and the identity of the Greek economy. Though the cooperative sector have had to meet urging agricultural, commercial and development needs, institutional and authoritative interventions by the state and political personnel severed its inner consistency and organizational effectiveness. To this date, this peculiarly disappointing under-development of the cooperative field in Greece persists, bearing grave economic and social consequences for the rural population, the commercial sector and the Greek economy in general.

1979 was the turning point for social entrepreneurship in Greece. Law 921/1979 and the following legislative initiatives provided for the emergence of social enterprises better formulated to cope with pressing issues on maintaining cohesion, enhancing employment and providing for an acceptable quality of life for volatile social groups. Nevertheless, since the introduction of the Limited Liability Social Cooperatives some years ago, no serious attempts were made to enrich social entrepreneurship institutional capacity with innovative organizational forms. Further structural deficiencies and the persistent nonrecognition of the social economy field left socially oriented economic activities somewhere between atypical and regrettably illegal (black) economy.

Law 4019/2011 on Social Economy and Social Entrepreneurship now provides for theinstitutional recognition of Social Economy in Greece for the first time. By introducing new forms of social entrepreneurship, such as the Social Cooperative Enterprise, it enriches the available organizational forms for economic self-expression. Under Law 4019/2011, Greece now possesses an integrated range of cooperatives potentially capable of materializing not only conventional but Social Economy visions along. Nevertheless, nor Law 4019 neither the Greek administrative system is yet able to address long standing issues regarding the structuration of social economy in Greece, through a detailed, operational and inclusive recognition. 


\section{References}

Archambault E. (1997) The Non Profit Sector in France. Manchester University Press.

Campbell R. Et al (ed). (2006) Voluntary Action: Meeting challenges of the $21^{\text {st }}$ century. NCVO.

CEP-CMAF. (2002) The Social Economy.

CIRIEC. (2000) The enterprises and organizations of the third system: a strategic challenge for employment. Pilot action "Third System and Employment" of the European Commission. Liege.

CIRIEC. (2007) Social Economy in the European Union. N ${ }^{\circ}$. CESE/

COMM/05/2005 European Economic and Social Committee (EESC).

Davister, C., Defourny J., Gregoire, O. (2004) Work Integration Social Enterprises. In the European Union: An overview of Existing Models, EMES Working Papers series, $\mathrm{N}^{\circ} 04 / 04$.

Defourny J. \& Develtere P. (1999) The Social Economy: A worldwide making of a Third Sector. In: Defourny J., Develtere P. \& Fonteneau B. (1999) L'économie sociale au Nord et au Sud. De Boeck.

Defourny J. \& Nyssens M. (2006) Social Enterprises at the crossroads. Routledge. Demoustier, D., \& Rousellier, D., 2005. Social economy as a Social Science :

Historical Perspectives on France. In Clary, J., Dolfsma, W., Figart, D., eds. Ethics and the Market: Insights from Social Economics, London \& New York : Routledge. EMES (2000) The emergence of social enterprise in Europe. New answers to social exclusion. Brussels.

Kalitsounakis D. (1929) 'History of Political Economy'. Archives of Economic and Social Sciences, Vol. 9, 1929.

Kazis L. (2005) Agricultural Cooperatives: Evolution, Importance, Perspective. CEDR Greek Report.

Lambos K. (1999) Cooperatives and development. Tipothito - Georgios Dardanos Editions.

Laville J., Levesque B. \& Mendell M. (2006) The social economy. Diverse approaches and practices in Europe and Canada. CRIDA.

Nasioulas I. (2010) The Social Economy of Greece and its social capital. An integrated institutional and national-accounting recognition. Orthos Logos Editions.

Nasioulas I. (2011, a). Social Economy in Greece. Lambert Academic Publishing. Nasioulas I. (2011, b). Greek Social Economy at the Crossroads. Law 4019/2011 and the institutionalization challenge. CIRIEC Working Papers, 2011/10. Nasioulas I. (2012). Greek Social Economy Revisited: Voluntary, Civic and Cooperative Challenges in the $21^{\text {st }}$ Century. Peter Lang Verlag. Papagarifallou P. (1973) The development of agricultural cooperatives in Greece from 1821 until 1940. Papazisis.

Papageorgiou K. (2004) Viable Cooperative Economy. Theory and practice.

Stamoulis Editions. 
Patronis V. (2001). Between state and market forces: Greek agricultural cooperative organization in transition period.

Pezaros (2004) A concise overview of Greek agriculture. Ministry of Agricultural Development and Food.

Pezaros P. (2004) A concise outlook of Greek agriculture. Ministry of Agricultural Development and Food.

PRI Project. (2006) What we need to know about social economy.

Rigos A. (1999) The Second Greek Republic 1924-1935. Social dimensions of the political scene. Themelio Editions.

Vienney C. (2008) The Social Economy. Polytropon Editions.

Websites:

Pharmacists' Cooperatives Federation (Greece) - www.osfe.gr

Cooperative Banks Union (Greece) - www.este.gr

Electricians' Cooperatives Federation (Greece) - www.posie.gr

Plumbers' Cooperatives Federation (Greece - www.ydro-poseyd.gr

Women's agro-tourist cooperatives (Greece) - www.europe-greece.com 